Tropical Journal of Pharmaceutical Research, June 2009; 8 (3): 231-237

(C) Pharmacotherapy Group, Faculty of Pharmacy, University of Benin,

Benin City, 300001 Nigeria.

All rights reserved.

Research Article

Available online at http://www.tjpr.org

\title{
Evaluation of the Antimicrobial Activity of Some Medicinal Plants against Enteric Bacteria with Particular Reference to Multi-Drug Resistant Vibrio cholerae
}

\author{
Saurabh Acharyya ${ }^{1}$, Amarendra Patra ${ }^{2}$ and Prasanta K. Bag ${ }^{1 *}$ \\ ${ }^{1}$ Department of Biochemistry, University of Calcutta, 35 Ballygunge, Circular Road, Kolkata-700019, ${ }^{2}$ Department of
} Chemistry, University of Calcutta, 92 Acharya Prafulla Chandra Road, Kolkata-700009, India

\begin{abstract}
Purpose: To evaluate the anti-enterobacterial potential of nine ethnobotanically selected plants traditionally used in different parts of India for the treatment of gastrointestinal disorders such as cholera, diarrhea or dysentery.

Methods: The methanol extracts of these plants were screened for antibacterial activity against 11 strains of enteropathogenic bacteria, including multi-drug resistant Vibrio cholerae (serotypes 01, 0139, and non-01, non-0139), using broth microdilution method. Ampicillin was used as a positive reference standard to determine the sensitivity of the strains. Phytochemical screening was carried out for phenolics and flavonoids.

Results: All of these plants had bactericidal activity against at least one of the test microorganisms with minimum inhibitory concentration (MIC) ranging from 0.125 to $32 \mathrm{mg} / \mathrm{ml}$ and minimum bactericidal concentration $(M B C)$ ranging from 0.25 to $32 \mathrm{mg} / \mathrm{ml}$. Among these, Terminalia chebula Retz. (Combretaceae) and Syzygium cumini (L.) Skeels (Myrtaceae) showed the most promising broad spectrum antibacterial properties, inhibiting all of the strains tested, especially Vibrio cholerae, Aeromonas hydrophila and Bacillus subtilis, with $M B C$ ranging from 0.25 to $4 \mathrm{mg} / \mathrm{ml}$. Phenolics and flavonoids were found to be present in the extracts.

Conclusion: The findings provide support for the use of this plant in traditional medicine for treatment of diarrheoa, especially cholera.
\end{abstract}

Keywords: Antimicrobial activity; Cholera; Diarrhea; Indian medicinal plants; Enteric bacteria; Indigenous

Received: 19 Nov 2008

Revised accepted: 14 Feb 2009

${ }^{*}$ Corresponding author: E-mail: pkbbioc@caluniv.ac.in; Fax: 91-33-2461 4849; Tel: 91-033-2461 5445

Trop J Pharm Res, June 2009; 8 (3):231 


\section{INTRODUCTION}

Morbidity and mortality due to diarrheoa continues to be a major problem in many developing countries, including India and Bangladesh, especially amongst children. Infections due to a variety of bacterial etiologic agents, such as pathogenic Escherichia coli, Vibrio cholerae, Areomonas spp., Shigella spp., Salmonella spp., Pseudomonas spp., Klebsiella spp., Campylobacter spp., and Staphylococcus aureus are most common. However, antibiotic resistance is a major clinical problem in treating infections caused by these microorganisms. Many readily available plants in India are used in traditional folklore medicine for the treatment of gastrointestinal disorders such as cholera, diarrhea and dysentery ${ }^{1-7}$. However, several of them have not been investigated from a pharmacological point of view to demonstrate their antibacterial properties, which could support their use as anticholera or antidiarrheal remedies in traditional medicine.

The objective of the present study was to evaluate the antibacterial activities of the extracts of some plants used in Indian traditional healthcare system, against a group of pathogenic bacteria. These plants are used by the indigenous people in different parts of India for the treatment of infectious diseases such as cholera, diarrhea, dysentery and other gastrointestinal disorders.

\section{EXPERIMENTAL}

\section{Plant materials}

We ethnobotanically selected nine Indian medicinal plants [Albizia lebbeck (L.) Benth. (Mimosaceae), Terminalia chebula Retz. (Combretaceae), Syzygium cumini (L.) Skeels (Myrtaceae), Solanum nigrum L. (Solanaceae), Picrorhiza kurrooa Royle ex Benth. (Scrophulariaceae), Butea monosperma (Lam.) Taub. (Papilionaceae), Saraca indica auct.non L. (Leguminosae), Aegle marmelos (L.) Correa ex Roxb.
(Rutaceae), and Withania somnifera (L.) Dunal (Solanaceae)] for antimicrobial screening in the present study. The plants were collected by the authors from the local area (West Bengal) and another region (Uttaranchal) in India. The botanical identification of the plant samples was carried out by Drs ABD. Selvan and Madhusudan Mandal of Botanical Survey of India (BSI), Central National Herbarium, Botanic Garden, Howrah, India. The voucher specimens are conserved at Central National Herbarium, BSI, Botanic Garden, Howrah, India. Plant species, local names, parts used, and the voucher specimen numbers are listed in Table 1.

\section{Other materials and reagents}

Among the clinical strains of $V$. cholerae used in this study, strains NB2 and SG24 belonged to 01 and 0139 serotypes, respectively. The other strains used in this study were $V$. cholerae non-O1, non-O139 (strains PC4 and PC65); Klebsiella pneumoniae strain PC36; A. hydrophila strain PC16; Escherichia coli strain PC80 (Enterotoxigenic Escherichia coli, ETEC) and E. coli strain VT3 (Enterohaemorrhagic E. coli, EHEC); Pseudomonas aeruginosa ATCC 15442; and Bacillus subtilis ATCC 6623. Antimicrobial susceptibility testing was performed by the disc diffusion method ${ }^{8}$ with commercially available disks (HiMedia, Mumbai, India) of ampicillin (A) $(10 \mu \mathrm{g})$; chloramphenicol $(\mathrm{C})(30$ $\mu \mathrm{g})$; co-trimoxazole (Co) (25 $\mu \mathrm{g})$; ciprofloxacin (Cf)(5 $\mu \mathrm{g})$; furazolidone (Fz) $(100 \mu \mathrm{g})$; gentamicin $(\mathrm{G})(10 \mu \mathrm{g})$; neomycin (N) $(30 \mu \mathrm{g})$; nalidixic acid (Na) $(30 \mu \mathrm{g})$; norfloxacin (Nx) $(10 \mu \mathrm{g})$; streptomycin (S) $(10$ $\mu \mathrm{g})$; tetracycline $(\mathrm{T})(30 \mu \mathrm{g})$.

\section{Preparation of extracts}

Plant extracts were prepared by macerating the air-dried plant part $(500 \mathrm{~g})$ with $2500 \mathrm{ml}$ of methanol in a Soxhlet apparatus for $18 \mathrm{~h}^{9}$. The extract was then filtered through Whatman no. 42 filter paper and concentra- 
Table 1: List of plant species with relevant information

\begin{tabular}{|c|c|c|c|}
\hline Species & $\begin{array}{l}\text { Local name } \\
\text { (parts of plant } \\
\text { used) }\end{array}$ & Voucher number & Traditional uses ${ }^{2-7}$ \\
\hline A. lebbeck & Chhatim (Bark) & $\mathrm{BSI} / \mathrm{CDM} / 019$ & Diarrheoa, piles \\
\hline T. chebula & Haritaki (Fruit) & $\mathrm{BSI} / \mathrm{CDM} / 424$ & Diarrheoa, indigestion, diabetes \\
\hline S. cumini & Jam (Seed) & BSI/PKB-SA/03 & $\begin{array}{l}\text { Diarrheoa, dysentery, piles, indigestion, } \\
\text { diabetes }\end{array}$ \\
\hline S. nigrum & $\begin{array}{l}\text { Kakamachi } \\
\text { (Fruit) }\end{array}$ & BSI/PKB-SA/04 & Diarrheoa, inflammation \\
\hline P. kurrooa & Kutki (Rhizomes) & $\mathrm{BSI} / \mathrm{CDM} / 315$ & Cholera, diarrheoa, dyspepsia \\
\hline B. monosperma & Palash (Flower) & $\mathrm{BSI} / \mathrm{CDM} / 063$ & $\begin{array}{l}\text { Diarrhea, piles, inflammation, skin } \\
\text { disease }\end{array}$ \\
\hline S. indica & Ashok (Flower) & BSI/PKB-SA/09 & Gastrointestinal disorder \\
\hline A. marmelos & Bel (Leaves) & BSI/PKB-SA/10 & $\begin{array}{l}\text { Cholera, diarrheoa, gastritis, vomiting, } \\
\text { diabetes }\end{array}$ \\
\hline W. somnifera & $\begin{array}{l}\text { Aswagandha } \\
\text { (root) }\end{array}$ & BSI/CDM/458 & $\begin{array}{l}\text { Diarrhea, dyspepsia, gastrointestinal } \\
\text { disorder }\end{array}$ \\
\hline
\end{tabular}

ted in a rotary vacuum evaporator (Eyela, Japan). The concentrated extract $(30 \mathrm{ml})$ was freeze-dried at $0.05 \mathrm{mbar}$ pressure and $60^{\circ} \mathrm{C}$ for $4 \mathrm{~h}$ in a LSL Secfroid lyophilizer (Lyolab BII, Aclens-Lausanne, Switzerland). The dried material was stored at $-20^{\circ} \mathrm{C}$ pending further use. The yield of each extract is shown in Table 1. Test samples were prepared by re-suspending the lyophilized powder in methanol.

\section{Antimicrobial assessment}

Isolates were considered susceptible, less susceptible, or resistant to a particular antimicrobial agent on the basis of the diameters of the inhibitory zones that matched the criteria of the manufacturer's interpretation table, which followed the recommendations of the National Committee for Clinical Laboratory Standards ${ }^{10}$. The American Type Culture Collection (ATCC) strains, Escherichia coli ATCC 25922 and
Staphylococcus aureus ATCC 25923, were used for quality control.

Minimum inhibitory concentration (MIC) and minimum bactericidal concentration (MBC) were assessed using the broth microdilution method $^{11}$. An inoculum of the microorganism was prepared from $24 \mathrm{~h}$ cultures grown in Mueller-Hinton broth (MHB) (HiMedia) and suspension was adjusted with a turbidity equivalent to that of a $0.5 \mathrm{McF}$ arland standard. The suspension was further diluted 1:10 in sterile MHB to obtain a final inoculum of $5 \times 10^{5} \mathrm{CFU} / \mathrm{ml}$. The 96 -well round bottom sterile plates were prepared by dispensing $180 \mu \mathrm{l}$ of the inoculated broth into each well. A $20 \mu \mathrm{l}$ aliquot of the plant extract was added. The concentrations of plant extract tested were $0.05,0.125,0.25,0.4,0.5,0.75$, $1,1.25,1.5,1.75,2,2.5,3,3.5,4,5,6,7,8$, $10,12,14,16,32 \mathrm{mg} / \mathrm{ml}$. Dilutions of ampicillin served as positive control, while broth with $20 \mu \mathrm{l}$ of methanol was used as negative control. 


\section{Haemolysis test}

Haemolysis test was employed to determine cellular toxicity of the extract as previously described $^{12}$. Plant extracts at concentrations ranging from 6 to $32 \mathrm{mg} / \mathrm{ml}$, were incubated with an equal volume of $1 \%$ human red blood cells in phosphate buffered saline $(10 \mathrm{mM}$ PBS, pH 7.4) at $37^{\circ} \mathrm{C}$ for $1 \mathrm{~h}$. Non-hemolytic and $100 \%$ hemolytic controls were the buffer alone and the buffer containing 1\% Triton X100 , respectively. Cell lysis was monitored by measuring the release of hemoglobin spectrophotometrically at $540 \mathrm{~nm}$.

\section{Phytochemical screening}

Phytochemical screening was performed following the method described previously ${ }^{13}$. For total phenolics, $0.2 \mathrm{ml}$ of plant extract $(5$ $\mathrm{mg} / \mathrm{ml}$ ) was diluted to $3 \mathrm{ml}$ with water and 0.5 $\mathrm{ml}$ of Folin-Ciocalteu reagent was added. Following incubation for $3 \mathrm{~min}$ at room temperature, $2 \mathrm{ml}$ of $20 \% \mathrm{w} / \mathrm{v} \mathrm{Na} \mathrm{NaO}_{3}$ was added. The mixture was heated in a boiling water bath for $1 \mathrm{~min}$ and allowed to cool to room temperature. It was centrifuged and the content of phenolics in the supernatant was determined spectrophotometrically at $650 \mathrm{~nm}$ (model U-2000, Hitachi), and expressed as $\mathrm{mg} / \mathrm{g}$ of gallic acid equivalents (GAE) per lyophylisate.

For total flavonoids, $0.2 \mathrm{ml}$ of dried extract (5 $\mathrm{mg} / \mathrm{ml}$ ) was diluted to $2 \mathrm{ml}$ with methanol, and $0.1 \mathrm{ml}$ of $10 \% \mathrm{w} / \mathrm{v}$ aluminium chloride, $0.1 \mathrm{ml}$ of $1 \mathrm{~mol} / \mathrm{lit}$ potassium acetate and $2.8 \mathrm{ml}$ of water were added sequentially. The mixture was then incubated at room temperature for $30 \mathrm{~min}$. Following centrifugation, the flavonoids content of the supernatant was measured spectrophotometrically at $415 \mathrm{~nm}$, and expressed as $\mathrm{mg} / \mathrm{g}$, based on rutin as standard.

\section{RESULTS}

The results of the tests are presented in Tables 2 - 4. The antibiotic susceptibility test of the clinical and environmental strains included here was performed to confirm their multi-drug resistance patterns. These were found to conform to multi-drug resistant. Antibiotic resistance patterns of $V$. cholerae, strains PC4, PC65, SG24 and NB2 were Fz$\mathrm{A}, \mathrm{A}-\mathrm{T}, \mathrm{Co}-\mathrm{S}$, and T-Na-Fz-Co-S, respectively.

The extracts of $T$. chebula and S. cumini had strong bactericidal activity with MIC ranging from 0.125 to $3 \mathrm{mg} / \mathrm{ml}$ and $\mathrm{MBC}$ ranging from 0.25 to $4 \mathrm{mg} / \mathrm{ml}$, against $V$. cholerae (serotypes O1, O139, and non-O1, nonO139) $A$. hydrophila, and $B$. subtilis; and moderate activity with MIC, $8-12 \mathrm{mg} / \mathrm{ml}$ and MBC ranging from 16.0 to $24.0 \mathrm{mg} / \mathrm{ml}$ against $P$. aeruginosa, ETEC and EHEC. S. nigrum was active against $V$. cholerae and did not show activity against $E$. coli and $P$. aeruginosa. The MBC of $P$. kurrooa extract was between 3 and $32 \mathrm{mg} / \mathrm{ml}$ against $V$. cholerae and $A$. hydrophila, but the extract was inactive against $E$. coli and $P$. aeruginosa. The flower extract of $B$. monosperma showed bactericidal activity against $V$. cholerae, $A$. hydrophila and $B$. subtilis with MBC ranging from 1.75 to 8 $\mathrm{mg} / \mathrm{ml}$. W. somnifera showed strong bactericidal activity (MBC, $2 \mathrm{mg} / \mathrm{ml}$ ) against $B$. subtilis and moderate activity against $V$. cholerae and $A$. hydrophila with MBC ranging from 16 to $32 \mathrm{mg} / \mathrm{ml}$. S. indica evoked strong bactericidal activity against $V$. cholerae and A. hydrophila with MBC ranging from 1 to 5 $\mathrm{mg} / \mathrm{ml}$ while $A$. lebbeck and $A$. marmelos had moderate activity against $V$. cholerae, $A$. hydrophila and $B$. subtilis. In addition, the bactericidal activity of $S$. indica against $E$. coli and $P$. aeruginosa was not observed within the concentration ranges of the extracts tested. Except for S. cumini (MIC, $24 \mathrm{mg} / \mathrm{ml}$ and $\mathrm{MBC}, 32 \mathrm{mg} / \mathrm{ml}$ ), all extracts were inactive against $K$. pneumoniae.

Phytochemical screening revealed that the crude methanol extracts contained phenolics $(10.6 \pm 0.9-365.9 \pm 16.1 \mathrm{mg} / \mathrm{g})$ and flavonoids $(0-65.6 \pm 2.8 \mathrm{mg} / \mathrm{g})$ (see Table 2). None of the extracts tested in the present study released haemoglobin and hence were not 
Acharyya et al

Table 2: Yield of plant extracts with their phenolic and flavonoid contents

\begin{tabular}{|c|c|c|c|}
\hline Species & $\begin{array}{l}\text { Yield (\% } \\
\text { w/w) }\end{array}$ & $\begin{array}{l}\text { Total phenolic } \\
\text { content }^{\mathrm{a}}\end{array}$ & $\begin{array}{l}\text { Total flavonoid } \\
\text { content }^{b}\end{array}$ \\
\hline A. lebbeck & 5.3 & $41.9 \pm 0.6$ & $3.0 \pm 1.0$ \\
\hline T. chebula & 47.6 & $365.9 \pm 16.1$ & $36.3 \pm 1.8$ \\
\hline S. cumini & 14.8 & $231.5 \pm 10.3$ & $27.0 \pm 0.9$ \\
\hline S. nigrum & 8.0 & $10.6 \pm 0.9$ & $7.3 \pm 0.9$ \\
\hline P. kurrooa & 35.6 & $56.9 \pm 2.6$ & $6.8 \pm 0.8$ \\
\hline B. monosperma & 27.0 & $136.5 \pm 5.6$ & $50.2 \pm 2.3$ \\
\hline S. indica & 9.3 & $106.9 \pm 1.2$ & $24.3 \pm 1.9$ \\
\hline A. marmelos & 11.2 & $68.0 \pm 2.8$ & $65.6 \pm 2.8$ \\
\hline W. somnifera & 5.0 & $11.4 \pm 0.5$ & - \\
\hline
\end{tabular}

Table 3: Minimum inhibitory concentration (MIC) and minimum bactericidal concentration (MBC) of plant extracts against multi-drug-resistant strains of $V$. cholerae serotypes $\mathrm{O} 1, \mathrm{O} 139$, and non-O1, non-O139

\begin{tabular}{|c|c|c|c|c|c|c|c|c|}
\hline \multirow{4}{*}{$\begin{array}{l}\text { Methanol } \\
\text { extract }\end{array}$} & \multicolumn{8}{|c|}{ Antibacterial activity (mg/ml) } \\
\hline & \multicolumn{8}{|c|}{ Strains } \\
\hline & \multicolumn{2}{|c|}{ SG24 (O139) } & \multicolumn{2}{|c|}{ NB2 (O1) } & \multicolumn{2}{|c|}{ PC4 (O26) } & \multicolumn{2}{|c|}{ PC65 (O48) } \\
\hline & $\stackrel{\mathcal{O}}{\Sigma}$ & $\begin{array}{l}\text { O } \\
\Sigma\end{array}$ & $\frac{\mathcal{O}}{\Sigma}$ & $\begin{array}{l}\text { O } \\
\Sigma\end{array}$ & $\stackrel{\mathcal{O}}{\Sigma}$ & $\stackrel{\text { O }}{\Sigma}$ & $\frac{O}{\Sigma}$ & $\stackrel{\text { OM }}{\Sigma}$ \\
\hline A. lebbeck & 24.0 & 24.0 & 16.0 & 16.0 & 16.0 & 24.0 & 16.0 & 16.0 \\
\hline T. chebula & 1.5 & 1.5 & 1.5 & 1.5 & 1.5 & 2.0 & 0.125 & 0.25 \\
\hline S. cumini & 1.5 & 1.8 & 1.25 & 1.25 & 2.5 & 3.0 & 2.0 & 2.0 \\
\hline S. nigrum & - & - & 8.0 & 12.0 & - & - & - & - \\
\hline P. kurrooa & 12.0 & 14.0 & 8.0 & 16.0 & - & - & 2.0 & 3.0 \\
\hline B. monosperma & 4.0 & 4.0 & 1.75 & 1.75 & 5.0 & 5.0 & 2.5 & 2.5 \\
\hline S. indica & 1.5 & 1.5 & 3.0 & 4.0 & 3.0 & 4.0 & 1.0 & 1.0 \\
\hline A. marmelos & 24.0 & 24.0 & 24.0 & 24.0 & 24.0 & 24.0 & 16.0 & 16.0 \\
\hline W. somnifera & 16.0 & 16.0 & 16.0 & 16.0 & 12.0 & 16.0 & 8.0 & 16.0 \\
\hline Ampicillin & 0.016 & 0.016 & 0.008 & 0.008 & $>1.0$ & ND & ND & ND \\
\hline
\end{tabular}

-, MIC/MBC was not obtained within the range of concentration (up to $32 \mathrm{mg} / \mathrm{ml}$ ) of the extract tested; ND, not determined. 
Table 4: Minimum inhibitory concentration (MIC) and minimum bactericidal concentration (MBC) of plant extracts against $A$. hydrophila, E. coli and $B$. subtilis

\begin{tabular}{|c|c|c|c|c|c|c|c|c|}
\hline \multirow{3}{*}{ Methanol extract } & \multicolumn{8}{|c|}{ Antibacterial activity (mg/ml) } \\
\hline & \multicolumn{2}{|c|}{ A. hydrophila PC16 } & \multicolumn{2}{|c|}{$\begin{array}{l}\text { E. coli VT3 } \\
\text { [EHEC] }\end{array}$} & \multicolumn{2}{|c|}{$\begin{array}{l}\text { E. coli PC80 } \\
\text { [ETEC] }\end{array}$} & \multicolumn{2}{|c|}{$\begin{array}{c}\text { B. subtilis } \\
\text { ATCC } 6623\end{array}$} \\
\hline & $\frac{\mathcal{O}}{\Sigma}$ & $\stackrel{\text { O }}{\Sigma}$ & $\stackrel{\mathcal{O}}{\Sigma}$ & $\stackrel{\text { O }}{\Sigma}$ & $\frac{\mathcal{O}}{\Sigma}$ & $\stackrel{0}{\Sigma}$ & $\frac{\mathcal{O}}{\Sigma}$ & $\stackrel{0}{\Sigma}$ \\
\hline A. lebbeck & 24.0 & 24.0 & - & - & - & - & 32.0 & - \\
\hline T. chebula & 1.0 & 2.0 & 12.0 & 12.0 & 14.0 & 16.0 & 1.0 & 4.0 \\
\hline S. cumini & 1.5 & 1.5 & 6.0 & - & 12.0 & 16.0 & 2.5 & 3.0 \\
\hline S. nigrum & ND & ND & - & - & - & - & ND & ND \\
\hline P. kurrooa & 12 & 12 & - & - & - & - & 8.0 & - \\
\hline B. monosperma & 8.0 & 8.0 & - & - & - & - & 6.0 & 8.0 \\
\hline S. indica & 5.0 & 5.0 & - & - & - & - & 1.5 & - \\
\hline A. marmelos & 32.0 & 32.0 & - & - & - & - & 32.0 & 32.0 \\
\hline W. somnifera & 32.0 & 32.0 & - & - & - & - & 2.0 & 2.0 \\
\hline Ampicillin & 0.032 & 0.032 & ND & ND & 1.0 & 1.0 & ND & ND \\
\hline
\end{tabular}

-, MIC/MBC was not obtained within the range of concentration (up to $32 \mathrm{mg} / \mathrm{ml}$ ) of the extract tested; ND, not determined.

cytotoxic to human erythrocytes at concentrations of up to $32 \mathrm{mg} / \mathrm{ml}$.

\section{DISCUSSION}

The extracts of the medicinal plants tested were effective antibacterial agents against a group of microorganisms that are implicated in either cholera, diarrheoa, dysentery or other gastrointestinal disorders. All of these plants had bactericidal activity against at least one of the test microorganisms with MIC ranging between 0.125 and $32 \mathrm{mg} / \mathrm{ml}$ and $\mathrm{MBC}$ between 0.25 and $32 \mathrm{mg} / \mathrm{ml}$. Among these, $T$. chebula and $S$. cumini showed the most promising broad spectrum antibacterial properties, inhibiting all of the strains tested, especially $V$. cholerae, $A$. hydrophila and $B$. subtilis, with MBC ranging between 0.25 and 4 $\mathrm{mg} / \mathrm{ml}$. Additionally, the extracts of $B$. monosperma, $P$. kurrooa, $S$. indica and $S$. nigrum showed strong bactericidal activity against $V$. cholerae. $W$. somnifera, $B$. monosperma, $A$. marmelos and $S$. indica, and were also active against the Gram-positive bacterium, $B$. subtilis. T. chebula showed bactericidal activity against the strain of EHEC, the causative agent of hemorrhagic colitis, dysentery and haemolytic uraemic syndrome (HUS).

It is interesting to note that the extracts of the plants used to treat cholera or diarrheoa in traditional Medicare systems ${ }^{2-7}$ were effective against the strains of $V$. cholerae, the causative agents of the dreadful disease, cholera, and cholera-like diseases. To the best of our knowledge, the plant extracts used in this study are being shown for the first time to demonstrate bactericidal activity against enterotoxigenic Escherichia coli (ETEC), enterohaemorrhagic $E$. coli (EHEC), $A$. hydrophila, and multi-serogroup strains of $V$. cholerae, the causative agents of different 
enteropathogenic outbreaks and sporadic diarrheoa. Phytochemical studies revealed that the crude methanol extracts contained phenolics and flavonoids and these compounds have previously been reported to possess antimicrobial activities.

\section{CONCLUSION}

The results of this study give some scientific credence to the indigenous uses of the Indian medicinal plants evaluated for the treatment of gastrointestinal disorders such as cholera and diarrheal diseases.

\section{ACKNOWLEDGEMENT}

This work and a fellowship to $S$. Acharyya were supported by grants from the Indian Council of Medical Research (ICMR), New Delhi, India.

\section{REFERENCES}

1. Chopra RN, Nayer SL, Chopra IC. Glossary of Indian Medicinal Plants (3rd Edn). Council of Scientific and Industrial Research, New Delhi (India), 1956; pp. 7-246.

2. Kala CP, Farooquee NA, Dhar U. Prioritization of medicinal plants on the basis of available knowledge, existing practices and use value status in Uttaranchal, India. Biodiversity and Conservation, 2004; 13: 453-469.

3. Kala CK. Ethnomedicinal botany of the Apatani in the Eastern Himalayan region of India. J Ethnobiol Ethnomed, 2005; 1: 11. [doi:10.1186/1746- 4269-1-11]

http://www.ethnobiomed.com/content/1/1/11 Accessed 16 November, 2005.

4. Maikhuri RK, Nautiyal S, Rao KS, Semwal RL. Indigenous knowledge of medicinal plants and wild edibles among three tribal subcommunities of the central Himalayas, India.
Indigenous Knowledge and Development Monitor, 2000; 8: 7-13.

5. Mukherjee PK, Saha K, Murugesan T, Mandal SC, $P$ al M, Saha BP. Screening of anti-diarrhoeal profile of some plant extracts of a specific region of West Bengal, India. Ethnopharmacol, 1998; 60: 85-89.

6. Muthu C, Ayyanar M. Raja N, Ignacimuthu $S$. Medicinal plants used by traditional healers in Kancheepuram District of Tamil Nadu, India. J Ethnobiol Ethnomed, 2006 2: 43. [doi:10.1186/1746-4269-2-43]. http://www.ethnobiomed.com/content/2/1/43. Accessed 7 October, 2005.

7. Nautiyal S, Rao KS, Maikhuri RK, Semwal RL, Saxena KG. Traditional knowledge related to medicinal and aromatic plants in tribal societies in a part of Himalaya. J Medicinal Aromatic Plant Sciences, 2000; 22/4a and 23/1A, 441528.

8. Bauer AW, Kirby WM, Sherris JC, Jurck M. Antibiotic susceptibility testing by a standardized single disc method. American J Pathol, 1996; 45: 493496.

9. Thakurta $P$, Bhowmik P, Mukherjee S, Hajra TK, Patra A, Bag PK. Antibacterial, antisecretory and antihemorrhagic activity of Azadirachta indica used to treat cholera and diarrhea in India. J Ethnopharmacol, $\quad 2007$; 111: $607-$ 612.

10. NCCLS. Performance standards for antimicrobial disk susceptibility testing, $12^{\text {th }}$ informational supplement. NCCLS document, 2002; M100S12. National Committee for Clinical Laboratory Standards, Wayne, Pa.

11. NCCLS. Methods for determining bactericidal activity of antimicrobial agents. Approved guideline, 1999; M26-A. National Committee for Clinical Laboratory Standards, Wayne, Pa.

12. Situ H, Bobek LA. In Vitro Assessment of Antifungal Therapeutic Potential of Salivary Histatin-5, Two Variants of Histatin-5, and Salivary Mucin (MUC7) Domain 1. Antimicrob Agents Chemother, 2000; 44: 14851493.

13. Edeoga HO, Okwu DE, Mbaebie BO. Phytochemical. Constituents of some Nigerian edicinal plants. African J Biotechnol, 2005; 4: 685-688. 